Article

\title{
Effects of Biochar and Synthetic Polymer on the Hydro-Physical Properties of Sandy Soils
}

\author{
Arafat Alkhasha ${ }^{1,2}$, Abdulrasoul Al-Omran ${ }^{1, *}$ and Anwar Aly 1,3 \\ 1 Soil Science Department, College of Food \& Agricultural Sciences, King Saud University, \\ P.O. Box 2460, Riyadh 11451, Saudi Arabia; aalkhasha@KSU.EDU.SA (A.A.-O.); aaaly@ksu.edu.sa (A.A.) \\ 2 General Authority for Agricultural Research, Sanaa 1837, Yemen \\ 3 Department of Soil and Water Science, Alexandria University, Alexandria 21545, Egypt \\ * Correspondence: rasoul@ksu.edu.sa; Tel.: +966-11467844; Fax: +966-114678440
}

Received: 13 October 2018; Accepted: 3 December 2018; Published: 6 December 2018

check for updates

\begin{abstract}
Synthetic polymers, such as polyacrylamide (PAM), and biochar are generally used as soil amendments to improve soil properties. This paper explores a laboratory column experiment conducted to investigate the effects of biochar (pyrolysis at $400-450{ }^{\circ} \mathrm{C}$ ) and polymers, with different application rates, on the hydro-physical properties of sandy soil. The experiment evaluated four rates each of biochar $\left(0.0 \%(\mathrm{C}), 2 \%\left(\mathrm{~B}_{1}\right), 4 \%\left(\mathrm{~B}_{2}\right), 6 \%\left(\mathrm{~B}_{3}\right)\right.$ and $\left.8 \%\left(\mathrm{~B}_{4}\right)\right)$ and polymers $\left(0.0 \%(\mathrm{C}), 0.2 \%\left(\mathrm{P}_{1}\right)\right.$, $0.4 \%\left(\mathrm{P}_{2}\right), 0.6 \%\left(\mathrm{P}_{3}\right)$, and $\left.0.8 \%\left(\mathrm{P}_{4}\right)\right)$, as well as a mixture of them. The infiltration rate decreased significantly when a mixture of biochar and polymers was adopted. $\mathrm{B}_{1}$ showed a decrease of $32.73 \%$ while a mixture of $8 \%\left(\mathrm{~B}_{4}\right)$ and $(0.8 \%) \mathrm{P}_{4}$ exhibited a decrease of $57.31 \%$. The polymers increased the infiltration rate at low concentrations $\left(\mathrm{P}_{1}\right.$ and $\left.\mathrm{P}_{2}\right)$ and reduced it at high concentrations $\left(\mathrm{P}_{3}\right.$ and $\left.\mathrm{P}_{4}\right)$. The cumulative evaporation decreased significantly for most treatments. $\mathrm{B}_{1}$ recorded the highest decrease in cumulative evaporation with a percentage decrease of $31.9 \%$. The highest decrease in hydraulic conductivity (Ks) was for $\mathrm{B}_{1}$. However, the mixture of $\mathrm{B}_{4}$ and $\mathrm{P}_{4}$ resulted in the highest increase in soil moisture content at field capacity compared to the control and other treatments. $\mathrm{P}_{4}$ and the mixture of $\mathrm{B}_{2}$ and $\mathrm{P}_{2}$ showed significant $(p<0.05)$ increases in the percentage of stable aggregate (SA) in fraction size $(0.25-0.125 \mathrm{~mm})$. Although the mixture of $\mathrm{B}_{4}$ and $\mathrm{P}_{4}$ had the highest increase in soil moisture content, this study recommends using the $\mathrm{B}_{1}$ treatment on sandy soil in arid environments due to its strong hydro-physical properties and affordability.
\end{abstract}

Keywords: soil amendments; polymer; biochar; infiltration rate; soil hydraulic properties; aggregate stability

\section{Introduction}

Soil amendments such as natural products (compost and manure) or synthetic polymers are used to sustain good soil properties and optimum water resources for crop production in arid and semi-arid regions. Application of suitable soil amendments to develop soil properties has become an increasingly common option to improve the sustainability of agriculture in arid and semi-arid areas. In addition, the application of appropriate soil amendments can considerably improve soil chemical, physical, and biological properties [1-3] and reduce the soil salinity and other stresses, i.e., water and nutrient deficiency [4].

Biochar material is a carbon (C) rich organic material that can be produced from farm crop residue, waste manure, and forest residue. Biochar is highly heterogeneous, has high porosity and large specific surface area, and is dependent on feedstock types and pyrolysis conditions such as air exposure, duration of combustion, and temperature [5]. 
Recently, the use of biochar in improving soil physical properties has been investigated by Obia et al. [5], Baiamonte et al. [6], and Laird et al. [7]. Obia et al. [5] evaluated the effects of maize cob biochar on the physical properties of sandy loam and loamy sand soils in fields of maize and soybeans. They found that bulk density decreased by $3-5 \%$ and porosity and available water capacity increased by $2-3 \%$ after adding biochar to the soil for both crops. Under soybeans crop, the soil aggregates stability increased by $4.6 \pm 1.9 \%$ and $6.8 \pm 1.9 \%$ for aggregates of $0.6-2$ and $2-6 \mathrm{~mm}$, respectively. While the stable soil aggregates for the maize crop increased by $2.6 \pm 1.9 \%$ and $2.9 \pm 1.9 \%$ for the $0.6-2$ and $2-6 \mathrm{~mm}$ aggregates, respectively.

Baiamonte et al. [6] studied the effects of different amounts of biochar on the structure of a sandy-clay soil. They revealed that progressive additions of biochar increased soil aggregate stability by enhancing the volume of drainable pores, field capacity, maximum available water, the stability ratio, and the saturated water content $(\theta \mathrm{s})$. Laird et al. [7] did not find significant influence of hardwood biochar on the soil saturated Ks. Asai et al. [8] and Uzoma et al. [9] observed that biochar application improved the soil saturated Ks. Novak et al. [10] reported significant differences in water retention capacity among soils treated with different biochar. Safari et al. [11] used the anionic PAM in a greenhouse experiment and found that the PAM significantly increased the mean weight diameter (MWD) and Ks. However, the beneficial effects of PAM on soil physical quality decreased over time. Hussien et al. [12] studied the effect of A poly[(acrylic acid)-co-acrylamide] hydrogel on Ks; they concluded that Ks values decrease at low concentrations of both polymers without additive and polymers with $5 \%(w / w)$ kaolinite clay mineral. The Ks values decreased significantly $(P<0.05)$ in the range $53.68-87.19 \%$ compared to the control.

Numerous researchers have reported that superabsorbent polymers (SAPs), also known as soil polymers or macromolecular polymers, are capable of repeatedly absorbing, retaining, and releasing extremely large amounts of water relative to their own weight. Thus, they can improve water conservation in soils, prevent deep percolation and soil nutrient loss, and maximize the efficient use of water and fertilizer [13-15]. SAPs can absorb more than a thousand times their original weight in water and they can retain liquids even under pressure [13]. SAPs have superior water absorption capacities relative to traditional absorbent materials, so they have been used widely in agriculture, horticulture, bioengineering, biomedicine, water purification, and food storage [15-18]. Hou et al. [19] reported that the use of organic-inorganic hybrid SAP (water absorbency rate $=500-600$ and $\mathrm{pH}=6.0-8.0$ ) with a rate ranging between 60 to $90 \mathrm{~kg} \mathrm{ha}^{-1}$ on a dry-farming region of Ningxia, China, led to significant decrease of soil bulk density and an increase of soil total porosity, crop water use efficiency, and final yield of potato compared with the control. Qin et al. [20] showed that the application of Wote (organic-inorganic hybrid) and microbe (microbial strain multifunctional preparation) SAPs could significantly increase the crop water use efficiency and enhance physical properties of soil. Wote SAPs exhibit a stronger effect than microbe SAPs. El-Asmar et al. [21] studied the use of polymer on clay and sandy-clay loam (SCL) soils with two pot experiments using Zea mays and Pinus pinea. They found that the polymer improves corn's fresh and dry aboveground biomass and prolongs survival time of pine seedlings in both soils. However, the polymer enhanced the water retention only in SCL soil and had negligible effect on clay soils. Furthermore, Alghamdi et al. [22] study the impact of bentonite (Ben), compost (Com), biochar (Bio) and mixture of them on soil physical and chemical characteristics and found that the mixture of Ben and Com, and Bio, Ben, and Com were the best in term of improving hydraulic properties of sandy soils. This study hypothesis that the biochar and polymer have their own advantages and by adding both can get all their advantages.

Therefore, the objective of this study was to investigate the effects of biochar, polymers, and mixtures of them on the hydro-physical properties of sandy soil.

\section{Materials and Methods}

The soil used in this experiment was collected from the educational farm of the College of Food and Agriculture Science, Riyadh Saudi Arabia, King Saud University $\left(24^{\circ} 44^{\prime} 13.4^{\prime \prime} \mathrm{N}\right.$, and $\left.46^{\circ} 37^{\prime} 06.7^{\prime \prime} \mathrm{E}\right)$. 
The soil sample was air dried for two days and passed through a 2-mm sieve. Chemical and physical properties were determined according to standard procedures [23]. The saturate soil paste extract was prepared and the salinity of the soil extract (ECe) was determined using electrical conductivity (EC) meter (test kit model 1500_20, Cole and Parmer) at $25^{\circ} \mathrm{C}$. While the $\mathrm{pH}$ were determined using $\mathrm{pH}$ meter (Hanna, $\mathrm{HI}$ 9811-5).The $\mathrm{Ca}^{+2}$ and $\mathrm{Mg}^{+2}$ were determined by titration with Ethylenediaminetetraacetic acid (EDTA), $\mathrm{Na}^{+}$and $\mathrm{K}^{+}$by flame photometer apparatus (Corning 400 ), $\mathrm{CO}_{3}{ }^{-2}$ and $\mathrm{HCO}_{3}{ }^{-}$by titration with acid, $\mathrm{Cl}^{-}$measured by titration with silver nitrate, and $\mathrm{SO}_{4}{ }^{-2}$ determined by turbidity method (Table 1).The texture determined by hydrometer method and the soil texture was loamy sand [23]. The bulk density of the soil in the column was $1.450 \mathrm{~g} \mathrm{~cm}^{-3}$.

Table 1. Physio-chemical properties of the soil and water.

\begin{tabular}{|c|c|c|c|c|c|c|c|c|c|c|c|}
\hline \multirow{2}{*}{ Sample } & \multirow{2}{*}{$\mathrm{pH}$} & \multirow{2}{*}{$\begin{array}{c}E C^{*} \\
\mathrm{dS} \cdot \mathrm{m}^{-1}\end{array}$} & \multicolumn{4}{|c|}{ Cations (meq $\mathrm{L}^{-1}$ ) } & \multicolumn{4}{|c|}{ Anions (meq $\mathrm{L}^{-1}$ ) } & \multirow{2}{*}{ O.M\% } \\
\hline & & & $\mathrm{Ca}^{+2}$ & $\mathrm{Mg}^{+2}$ & $\mathrm{Na}^{+1}$ & $\mathrm{~K}^{+1}$ & $\mathrm{Cl}^{-1}$ & $\mathrm{HCO}_{3}{ }^{-1}$ & $\mathrm{CO}_{3}{ }^{-2}$ & $\mathrm{SO}_{4}{ }^{-2}$ & \\
\hline Soil & 7.55 & 2.46 & 10.92 & 2.25 & 6.58 & 5.10 & 2.50 & 0.83 & 0.00 & 19.83 & 0.45 \\
\hline Water & 7.30 & 0.73 & 1.50 & 1.83 & 3.83 & 0.08 & 3.67 & 1.30 & 0.00 & 2.30 & - \\
\hline
\end{tabular}

* EC (electrical conductivity) of Soil = Soil ECe.

\section{Production and Characterization of Biochar.}

Biochar was produced from date palm residuals such as fronds and rachis that were exposed to direct sunlight to dry out and then cut down to small pieces $(10-15 \mathrm{~cm})$. The date palm pieces were packed tightly in a stainless-steel cylinder $(50 \mathrm{~cm}$ radius and $80 \mathrm{~cm}$ length) to minimize air volume and to provide nearly oxygen-free conditions. The container was tightly covered and subject to outdoor pyrolysis at a temperature of $400-450{ }^{\circ} \mathrm{C} \pm 10{ }^{\circ} \mathrm{C}$. The biochar had a $\mathrm{pH}$ of $9.85, \mathrm{EC}$ of $1.23 \pm 0.2 \mathrm{dS} \mathrm{m}^{-1}$, biochar-to-water ratio of 1:10, and a bulk density of $0.33 \mathrm{~g} \mathrm{~cm}^{-3}$.

The biochar was passed through a 2-mm sieve, and then mixed with soil at ratios of 20, 40, 60 and $80 \mathrm{~g} \mathrm{~kg}^{-1}$ (hereafter referred to as $\mathrm{B}_{1}, \mathrm{~B}_{2}, \mathrm{~B}_{3}$, and $\mathrm{B}_{4}$ ). The bulk density of the mixtures of soil and biochar was calculated based on the following equation [24]:

$$
\rho_{\mathrm{b}}=\frac{100}{\left[\left(\frac{\mathrm{x}}{\rho_{1}}\right)+\frac{(100-\mathrm{x})}{\rho_{2}}\right]}
$$

where $\rho_{b}$ is the bulk density of the mixtures $\left(\mathrm{g} \mathrm{cm}^{-3}\right), \mathrm{x}$ is the percentage by weight of biochar, $\rho_{1}$ is the bulk density of biochar $\left(\mathrm{g} \mathrm{cm}^{-3}\right)$, and $\rho_{2}$ is the soil bulk density $\left(\mathrm{g} \mathrm{cm}^{-3}\right)$. Based on Equation (1) the bulk densities of different biochar amended soils were $1,0.99,0.99$, and $0.98 \mathrm{~g} \mathrm{~cm}^{-3}$, respectively.

\section{Polymer: Polyacrylamide}

The SAP (commercial name PagriSap) was purchased from Riyadh agriculture facility. The polymer is polyacrylamide (produced by Polykem Sarl, Switzerland) with $\mathrm{pH}=7.51$ and $\mathrm{EC}=2.12 \mathrm{dSm}^{-1}$ (measured in 1:10 extract by EC and pH meters (Hanna, HI 9811-5)). Infrared Spectroscopy (FT-IR) was used for polymer identification (FT-IR, Bruker Optic Tensor27, Germany). The FT-IR spectrum of polymer hydrogel shows many characteristic bands. The band at approximately $3433 \mathrm{~cm}^{-1}$ is attributed to the $-\mathrm{OH}$ stretching vibrations while the peak at 2928 and $2863 \mathrm{~cm}^{-1}$ were assigned to $-\mathrm{CH}$ stretching and vibration. The band at $1664 \mathrm{~cm}^{-1}$ is related to carbonyl group stretching. The band at $1562 \mathrm{~cm}^{-1}$ is assigned to the stretching mode of $-\mathrm{C}=\mathrm{C}-$ groups. Additional bands at 1448,1400 and $1350 \mathrm{~cm}^{-1}$ are attributed to $-\mathrm{O}-\mathrm{CH}_{3}$ and vibration of the hydroxyl group. The strong peak at $1113 \mathrm{~cm}^{-1}$ was assigned to the $\mathrm{C}-\mathrm{O}-\mathrm{C}$ group [25] (Figure 1).

The polymer was mixed with soil at ratios of $2,4,6$ and $8 \mathrm{~g} \mathrm{~kg}^{-1}$ (hereafter referred to as $\mathrm{P}_{1}, \mathrm{P}_{2}$, $\mathrm{P}_{3}$, and $\mathrm{P}_{4}$ ). The mixture of biochar and polymer with soil at ratios of 20:2, 40:4, 6:60, and 8:80 $\mathrm{g} \mathrm{kg}^{-1}$ are hereafter referred to as $\mathrm{B}_{1}: \mathrm{P}_{1}, \mathrm{~B}_{2}: \mathrm{P}_{2}, \mathrm{~B}_{3}: \mathrm{P}_{3}$, and $\mathrm{B}_{4}: \mathrm{P}_{4}$, respectively. 


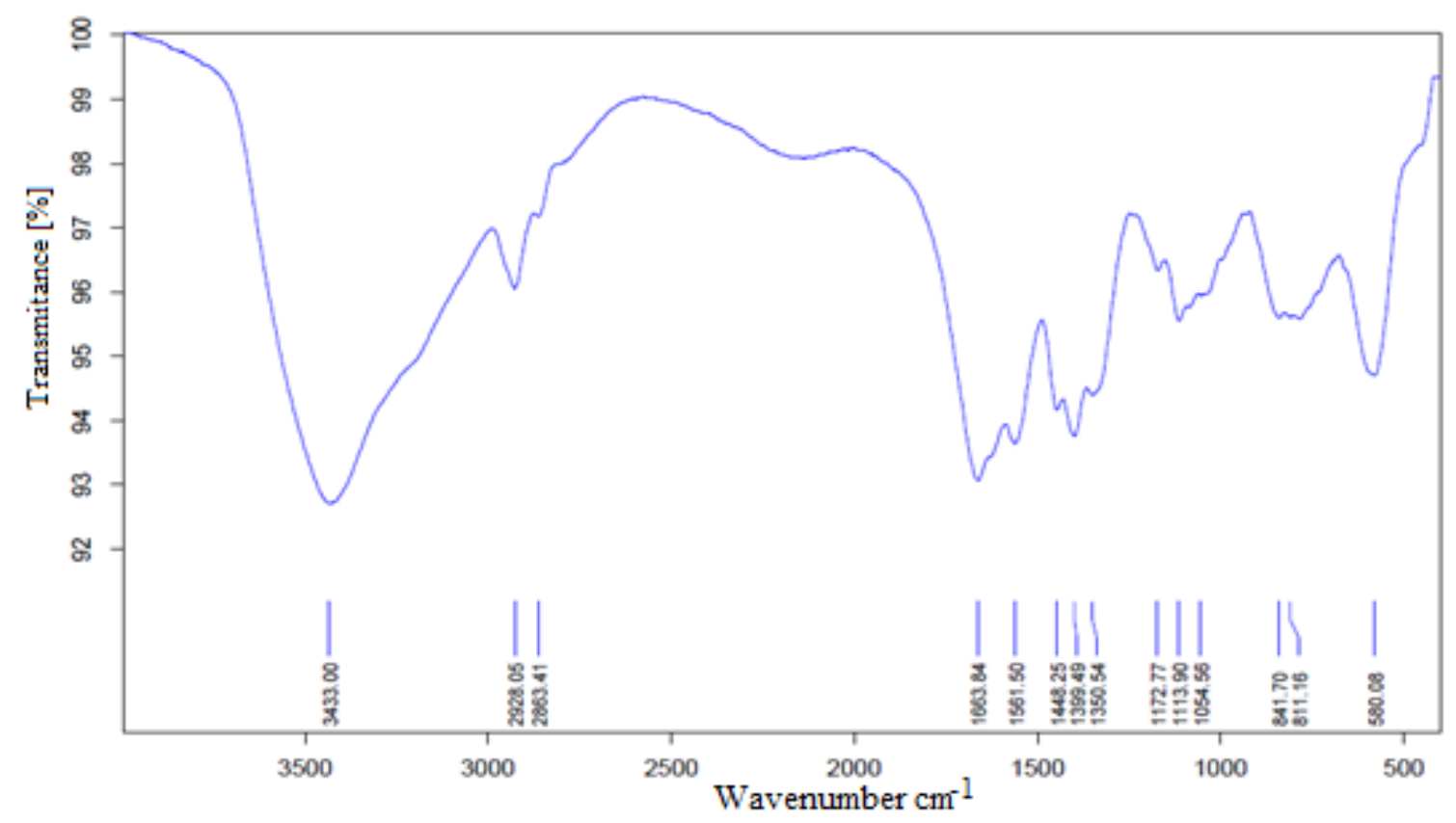

Figure 1. FT-IR spectrum of the polymer used.

\section{Intermittent Evaporation}

Soil columns made of a transparent plastic with an internal diameter of $5 \mathrm{~cm}$ and length of $40 \mathrm{~cm}$ were used in this experiment. The columns were sealed from the end by two filter papers and a piece of gauze fabric firmly held using tape and string. The columns were filled with the soil to $30 \mathrm{~cm}$ height with an adjusted bulk density of $1.5 \mathrm{~g} \mathrm{~cm}^{-3}$. All treatments were mixed with soil and added thoroughly to the top $10 \mathrm{~cm}$ of the soil columns. The columns were mounted vertically on a wooden holder inside the laboratory and kept at a controlled temperature of $22{ }^{\circ} \mathrm{C} \pm 2{ }^{\circ} \mathrm{C}$ [26]. $25 \mathrm{~mL}$ of tap water (EC of $0.73 \mathrm{dS} \mathrm{m}^{-1}$ ) was added weekly for five wetting/drying cycles. Each treatment was replicated three times. Cumulative evaporation against time was recorded each day by weighing the soil columns. After five weeks, soil columns were divided at $2.5 \mathrm{~cm}$ intervals to a depth of $10 \mathrm{~cm}$, then at $5 \mathrm{~cm}$ intervals subsequently. Soil water content was measured gravimetrically, and the distribution of the soil water with depth was determined. The water conserved amount in each column was calculated using the water content and cumulative evaporation data [26,27].

\section{Infiltration Experiment}

Infiltration was measured using a mini disk infiltrometer (model M12, 2-cm suction; Decagon Devices, Pullman, WA, USA). Soil columns described in the intermittent evaporation section were used for all treatments. The disk infiltrometer was placed in water before the stated measurement to ensure the mini disc was saturated, and then filled with water carefully to avoid air bubbles. The disk infiltrometer was in full contact with the soil surface at the beginning of the measurements and continuing for 10 or 15 min depending on the treatment. The volume of water infiltrating and the position of the wetting front was recorded every minute. The cumulative infiltration (CI) calculated according to Philip [28]:

$$
\mathrm{I}=\mathrm{St}^{0.5}+\mathrm{A}_{1} \mathrm{t}
$$

where $\mathrm{I}$ is the $\mathrm{CI}$ (in $\mathrm{cm}$ ), $\mathrm{S}$ is the sorptivity $\left(\mathrm{cm} \mathrm{min}{ }^{-0.5}\right), \mathrm{A}_{1}$ is a constant related to the $\mathrm{Ks}$, and $\mathrm{t}$ is time in minutes. A mathematical representation for Equation (2) obtained by plotting CI against the 
square root of time, and a second-order polynomial was fitted to the measured data. The infiltration rate was calculated as the first derivative of the $\mathrm{CI}$ according to the relation:

$$
\mathrm{i}=0.5 \mathrm{St}^{-0.5}+\mathrm{A}_{1}
$$

We obtained a mathematical representation for Equation (3) by plotting the infiltration rate against $1 /\left(2 t^{0.5}\right)$ and fitting a linear equation to the measured data.

\section{Hydraulic Conductivity}

Saturated Ks was measured by constant head method technique, and measurements of Ks of saturated soils in the laboratory were based on the direct application of Darcy's equation to a saturated soil column of uniform cross-sectional area [29]. A hydraulic-head difference was imposed on the soil column, and out flux of water was measured. The saturated Ks can be calculated as follows:

$$
\mathrm{K}_{\mathrm{s}}=\frac{(\mathrm{QL})}{(\mathrm{AtH})}
$$

where $K_{s}$ is the saturated hydraulic conductivity, $Q$ is the volume of water, $L$ is the length of the soil column, $\mathrm{A}$ is the cross-sectional area of the soil sample, $\mathrm{t}$ is the time required for the volume of water $\mathrm{Q}$ to be discharged, and $\mathrm{H}$ is the water head.

\section{Soil Aggregate Stability}

Soil aggregate stability was determined by a wet sieving apparatus as described by Nimmo and Perkins [30]. $2 \mathrm{~mm}$ air-dried aggregates with a weight of $40 \mathrm{~g}$ were separated manually by moving the sieves up and down by approximately $3 \mathrm{~cm}$ in water 30 times during a $2 \mathrm{~min}$ period. The sieving continued until only the sand particles were left on the sieves. The aggregates remaining on each sieve were collected and oven dried at $105^{\circ} \mathrm{C}$ for $24 \mathrm{~h}$. The fractions between 1 and $2 \mathrm{~mm}$ were corrected by removing the weight of sand to avoid overestimation. The proportion of sand assumed as constant in every size fraction retained in the eight sieves was used according to the method described in Lal and Schukla [31], as follows:

$$
\mathrm{SA}=\frac{(\text { weight retained })-(\text { weight of sand fraction })}{(\text { total sample weight })-(\text { weight of sand })} * 100
$$

The MWD can be calculated using the following equation [32]:

$$
\mathrm{MWD}=\sum_{\mathrm{i}=1}^{\mathrm{n}} \mathrm{x}_{\mathrm{i}} \mathrm{w}_{\mathrm{i}}
$$

where $x_{i}$ is the mean diameter of the size fraction $i$ that corresponds to the mean aperture of the adjacent sieves, $\mathrm{w}_{\mathrm{i}}$ is the proportion of the total sample weight remaining on each sieve after sieving, and $\mathrm{n}$ is the number of aggregate sizes ( 8 sizes).

\section{Soil Water Retention}

Several soil water parameters were measured, including soil water content at 100 and 15,000 hPa retention representing field capacity (F.C) and permanent wilting (WP), respectively. In addition, the water retention curves were determined using a pressure plate extractor for a range of water potentials. The Retention Curve (RETC) program was used to fit the parameters ( $\theta \mathrm{s}, \theta \mathrm{r}, \alpha$ and $\mathrm{n}$ ) for the van Genuchten model. 


\section{Statistical Analysis}

Measurements were conducted in triplicate, and data analyzed using a one-way analysis of variance with biochar and polymer application rate as the independent variable. Statistical analysis was performed using the software SPSS for Windows (version 18, SPSS Inc. Chicago, IL, USA). The least significant difference (LSD at $p<0.05)$ test was applied to assess the differences among the means of treatments.

\section{Results}

\subsection{Intermittent Evaporation}

Effects of biochar, polymers, and amended soil on cumulative evaporation (CE) and water retained are shown in Table 2. At the end of the wetting and evaporation cycles, the total amount of water added to the soil columns during the five cycles was $63.69 \mathrm{~mm}$. The amount of water recovered from evaporation and water conserved varied between $93.54 \%$ and $99.37 \%$ and is shown in Table 2 and Figure 2. The addition of biochar significantly reduced evaporation for each cycle. The reductions in $\mathrm{CE}$ at the end of five cycles were $29.27 \%, 16.47 \%, 14.17 \%$, and $14.61 \%$ for $\mathrm{B}_{1}, \mathrm{~B}_{2}, \mathrm{~B}_{3}$, and $\mathrm{B}_{4}$, respectively. The $B_{2}$ treatment resulted in a lower $C E$ than other treatments of biochar. However, increasing the biochar rate to $8 \%$ slightly increased $\mathrm{CE}$ when compared to control. In contrast, the use of polymers, especially with high rate of application $\left(\mathrm{P}_{4}\right)$, increased the CE. The increases in CE were $6.87 \%, 13.8 \%$, and $14.86 \%$, for $\mathrm{P}_{2}, \mathrm{P}_{3}$, and $\mathrm{P}_{4}$, respectively. The application of $\mathrm{P}_{1}$ decreased CE by $10.77 \%$ that of the untreated soil. Conversely, the application of mixture treatments of biochar and polymer reduced the CE by $17.40 \%, 9.25 \%, 0.55 \%$, and $0.9 \%$ for $\mathrm{B}_{1}: \mathrm{P}_{1}, \mathrm{~B}_{2}: \mathrm{P}_{2}, \mathrm{~B}_{3}: \mathrm{P}_{3}$, and $\mathrm{B}_{4}: \mathrm{P}_{4}$, respectively.

Table 2. Evaporation and the water retained after wetting/evaporation cycles for fresh water. Water added for each treatment was $63.69 \mathrm{~mm}$.

\begin{tabular}{|c|c|c|c|c|c|c|c|c|}
\hline \multirow{2}{*}{ Treatment } & \multicolumn{5}{|c|}{ Evaporation (mm) } & \multirow{2}{*}{$\begin{array}{c}\text { Cumulative } \\
\text { Evaporation } \\
(\mathrm{mm})\end{array}$} & \multirow{2}{*}{$\begin{array}{c}\text { Water } \\
\text { Retained } \\
(\mathrm{mm})\end{array}$} & \multirow{2}{*}{$\begin{array}{c}\text { Recovery } \\
\%\end{array}$} \\
\hline & Week 1 & Week 2 & Week 3 & Week 4 & Week 5 & & & \\
\hline Control & $5.99 a^{*}$ & $8.80 \mathrm{a}$ & $12.45 \mathrm{a}$ & $13.83 \mathrm{a}$ & $13.83 \mathrm{a}$ & $54.90 \mathrm{a}$ & $7.98 \mathrm{~d}$ & 98.72 \\
\hline B1 & $4.36 \mathrm{c}$ & $6.89 \mathrm{e}$ & $9.60 \mathrm{~d}$ & $9.63 \mathrm{~b}$ & $8.36 \mathrm{~d}$ & $38.83 \mathrm{e}$ & $23.60 \mathrm{a}$ & 98.02 \\
\hline B2 & $5.04 \mathrm{c}$ & $7.56 \mathrm{c}$ & $11.02 \mathrm{~b}$ & $11.90 \mathrm{~d}$ & $10.33 c$ & $45.86 \mathrm{~d}$ & $16.60 \mathrm{~b}$ & 98.06 \\
\hline B3 & $4.70 \mathrm{~d}$ & $7.46 \mathrm{~d}$ & $10.95 \mathrm{c}$ & $12.17 b$ & $11.85 \mathrm{~b}$ & $47.12 \mathrm{~b}$ & $15.60 \mathrm{c}$ & 98.47 \\
\hline B4 & $5.35 \mathrm{~b}$ & $7.91 \mathrm{~b}$ & $11.05 \mathrm{~b}$ & $12.18 \mathrm{~b}$ & $10.39 c$ & $46.88 \mathrm{c}$ & $15.80 \mathrm{c}$ & 98.41 \\
\hline $\operatorname{LSD}_{(0.05)}$ & 0.289 & 0.289 & 0.034 & 0.577 & 0.188 & 1.76 & 0.275 & - \\
\hline P1 & $4.98 \mathrm{c}$ & $8.28 \mathrm{~d}$ & $11.49 \mathrm{~d}$ & $12.63 \mathrm{~b}$ & $11.60 \mathrm{c}$ & $48.99 \mathrm{~d}$ & $12.10 \mathrm{a}$ & 95.90 \\
\hline P2 & $5.25 \mathrm{~b}$ & $9.61 \mathrm{~b}$ & $14.05 \mathrm{c}$ & $15.22 \mathrm{a}$ & $14.54 \mathrm{~b}$ & $58.67 \mathrm{c}$ & $2.10 \mathrm{~b}$ & 95.41 \\
\hline P3 & $5.89 \mathrm{a}$ & $8.97 \mathrm{c}$ & $14.51 \mathrm{~b}$ & $16.26 \mathrm{a}$ & $16.85 \mathrm{a}$ & $62.48 \mathrm{~b}$ & $0.30 \mathrm{c}$ & 98.56 \\
\hline $\mathrm{P} 4$ & $5.56 \mathrm{~b}$ & $10.5 \mathrm{a}$ & $14.87 \mathrm{a}$ & $15.67 \mathrm{a}$ & $16.46 \mathrm{~b}$ & $63.06 \mathrm{a}$ & $0.24 \mathrm{c}$ & 99.37 \\
\hline $\operatorname{LSD}_{(0.05)}$ & 0.225 & 0.120 & 0.027 & 0.485 & 0.184 & 1.41 & 0.208 & - \\
\hline $\mathrm{B} 1: \mathrm{P} 1$ & $5.04 \mathrm{~b}$ & $7.70 \mathrm{c}$ & $11.36 \mathrm{~d}$ & $11.68 \mathrm{~b}$ & $9.58 \mathrm{~d}$ & $45.35 \mathrm{~b}$ & $16.68 \mathrm{a}$ & 97.38 \\
\hline B2:P2 & $5.20 \mathrm{a}$ & $8.48 b$ & $12.05 \mathrm{c}$ & $12.87 \mathrm{a}$ & $11.22 \mathrm{c}$ & $49.82 \mathrm{a}$ & $12.43 \mathrm{a}$ & 97.73 \\
\hline B3:P3 & $5.38 \mathrm{a}$ & $9.21 \mathrm{a}$ & $12.92 \mathrm{~b}$ & $13.99 \mathrm{a}$ & $13.09 \mathrm{a}$ & $54.60 \mathrm{a}$ & $7.65 c$ & 97.73 \\
\hline B4:P4 & $5.43 \mathrm{a}$ & $9.28 \mathrm{a}$ & $13.06 \mathrm{a}$ & $14.04 \mathrm{a}$ & $12.59 \mathrm{~b}$ & $54.40 \mathrm{a}$ & $7.98 b$ & 97.94 \\
\hline $\operatorname{LSD}_{(0.05)}$ & 0.324 & 0.324 & 0.081 & 0.572 & 0.184 & 1.85 & 0.297 & - \\
\hline
\end{tabular}

${ }^{*}$ Means in columns followed by the same letter are not significantly different at $P<0.05$ using the least significant difference (LSD) test. 

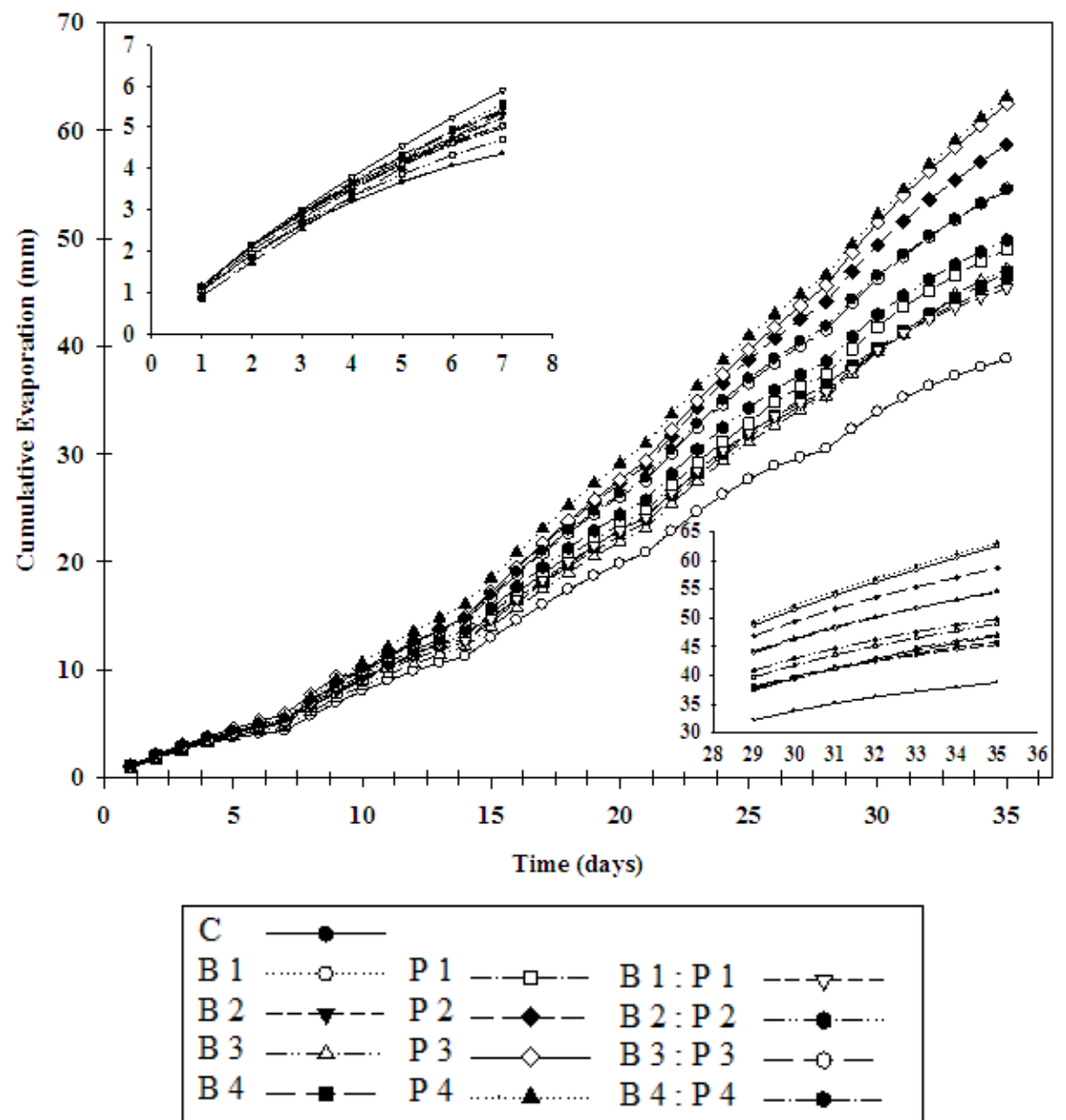

Figure 2. Effect of biochar, polymer, and mixtures on cumulative evaporation (in $\mathrm{mm}$ ) after 5 weeks of wetting/evaporation cycles.

\subsection{Water Conserved}

Table 2 shows the amount of water conserved of the end of the fifth cycle as affected by soil amendment type and rates. The amount of water conserved by each of the amendments is ranked as follows: $B_{1}>B_{1}: P_{1}>B_{2}>B_{4}>B_{3}>B_{2}: P_{2}>P_{1}>$ control $>B_{4}: P_{4}>B_{3}: P_{3}>P_{2}>P_{3}>P_{4}$. The results show that the biochar gave better results at any rate, while the polymer showed good results only at low concentrations. The least amount of water conserved was observed at higher concentrations of polymer.

\subsection{Infiltration}

Figure 3 shows the $\mathrm{CI}$ as affected by biochar and polymer applications (Figure 3a). The CI was reduced by increasing the biochar rate. The percentage decreases of CI were $34.38 \%, 43.37 \%$, $58.89 \%$, and $57.07 \%$, for $\mathrm{B}_{1}, \mathrm{~B}_{2}, \mathrm{~B}_{3}$, and $\mathrm{B}_{4}$, respectively. The addition of polymer increased the $\mathrm{CI}$ for all treatment rates, except treatment $\mathrm{P}_{3}$, where $\mathrm{CI}$ decreased by $7.5 \%$ compared to control. The $\mathrm{CI}$ increased with polymer addition by $19.17 \%, 22.20 \%$, and $6.33 \%$ for $\mathrm{P}_{1}, \mathrm{P}_{2}$, and $\mathrm{P}_{4}$, respectively. The biochar and polymer mixture treatment led to decreases in CI by $32.12 \%, 56.45 \%, 52.40 \%$, and $57.43 \%$ with the additions of $B_{1}: P_{1}, B_{2}: P_{2}, B_{3}: P_{3}$, and $B_{4}: P_{4}$, respectively, compared to untreated soil. The largest decrease in $\mathrm{CI}$ was observed with the addition of biochar followed by the mixture, as shown in Figure $3 b$, with the equation constant presented in a supplementary file.

The addition of biochar and polymers also affected the infiltration rate as shown in Figure 3c. The decreased infiltration rates for the biochar and mixture treatment were $32.73 \%, 42.17 \%, 57.82 \%$, 
$56.85 \%, 4.72 \%, 30.81 \%, 57.58 \%, 52.05 \%$, and $57.31 \%$ for $\mathrm{B}_{1}, \mathrm{~B}_{2}, \mathrm{~B}_{3}, \mathrm{~B}_{4}, \mathrm{P}_{3}, \mathrm{~B}_{1}: \mathrm{P}_{1}, \mathrm{~B}_{2}: \mathrm{P}_{2}, \mathrm{~B}_{3}: \mathrm{P}_{3}$, and $\mathrm{B}_{4}: \mathrm{P}_{4}$, respectively. In contrast, the polymer increased the infiltration rate by $21.87 \%, 25.82 \%$, and $9.32 \%$ for $\mathrm{P}_{1}, \mathrm{P}_{2}$, and $\mathrm{P}_{4}$, as shown in Figure $3 \mathrm{~d}$, when compared to the control treatment, with the equation constant presented in supplementary file.

\subsection{Saturated Hydraulic Conductivity}

Figure 4 shows the $\mathrm{K}_{\mathrm{s}}$ values for soil amendment with biochar, polymer, and mixtures of biochar and polymer. The $\mathrm{K}_{\mathrm{s}}$ values decreased significantly for mixture application rate $\mathrm{B}_{2}: \mathrm{P}_{2}(2 \%$ and $0.2 \%)$ compared with untreated soil. In addition, the $\mathrm{K}_{\mathrm{s}}$ value decreased more with biochar application rate $\mathrm{B}_{1}$. Thus, with application of biochar and polymer, the average value of decrease was $85.35 \%$ and $53.98 \%$ for $B_{1}$ and $B_{2}$, respectively.
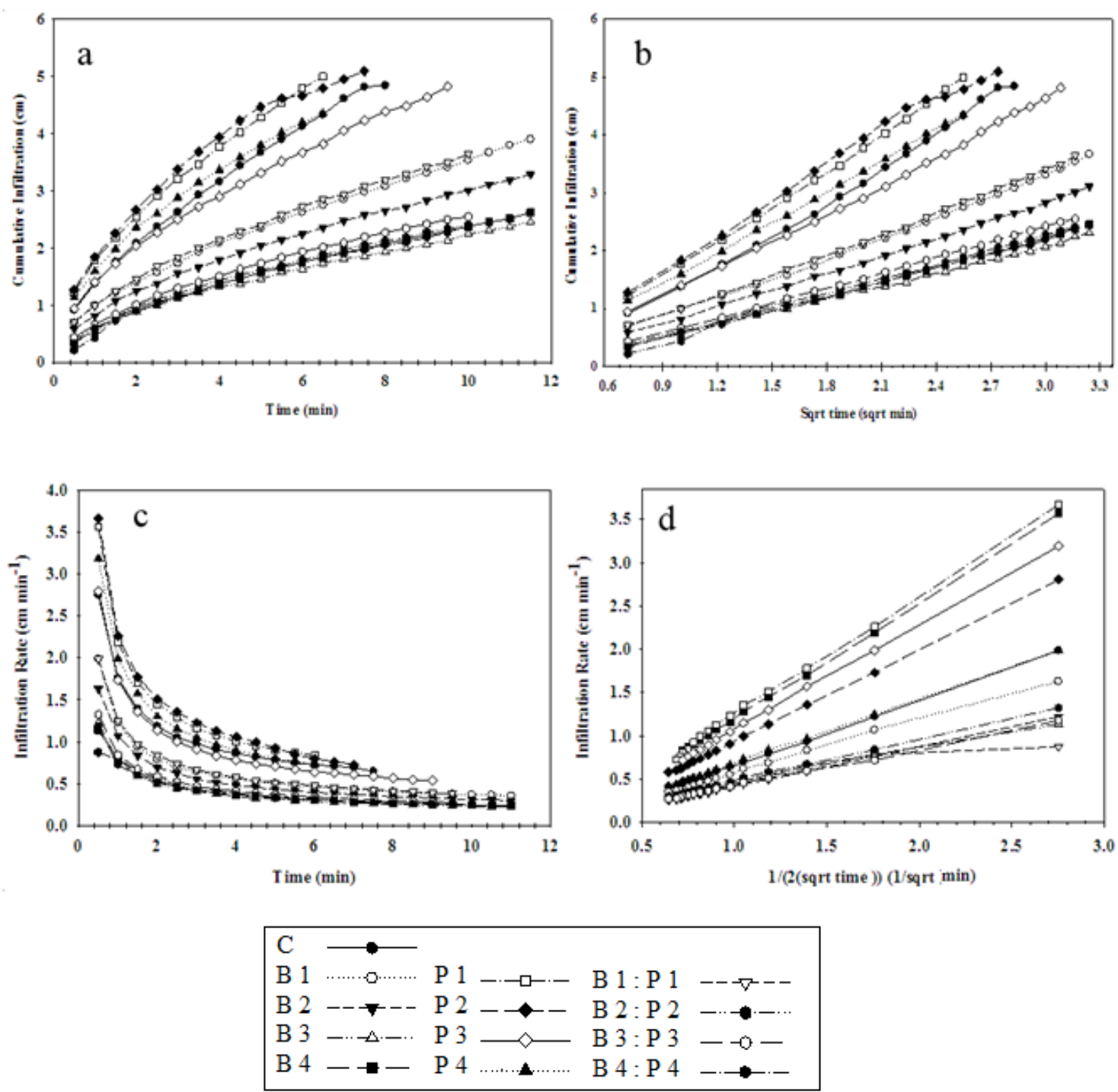

Figure 3. Effect of (biochar, polymer and mixture) applications on cumulative infiltration (a) and infiltration rate (c). Mathematical representation of cumulative infiltration and infiltration rate were obtained by fitting a second-order polynomial to measured cumulative infiltration versus the square root of time $\left(\mathrm{t}^{0.5}\right)(\mathbf{b})$ and by fitting a linear equation to measured infiltration rate versus $1 /\left(2 \mathrm{t}^{0.5}\right)(\mathbf{d})$, (fresh water) respectively. 


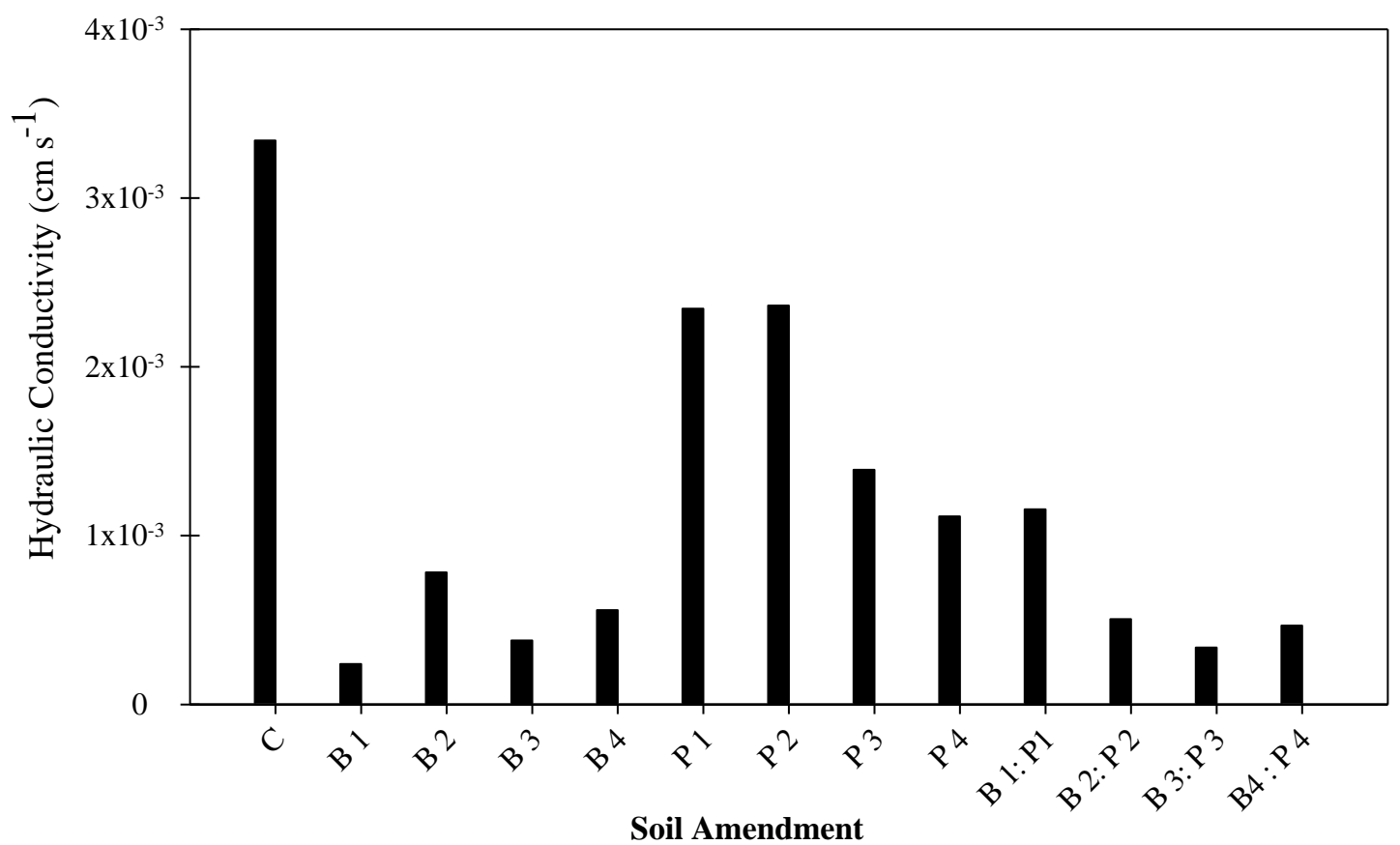

Figure 4. Effect of biochar, polymer, and mixture applications on hydraulic conductivity using fresh water.

\subsection{Soil Moisture Distribution}

Figure 5 shows the soil moisture distribution (SMD) profile for the soil column with depth at the end of the evaporation experiment. The largest increase in soil moisture content as compared to the untreated soil was found $5-10.5 \mathrm{~cm}$ from the surface, followed by the top surface $(0-2.5 \mathrm{~cm})$. The percentage of increase in soil moisture content ranged between $6.84 \%$ and $68.03 \%$, depending on the soil amendment. Additionally, biochar increased soil moisture content $68.03 \%, 54.36 \%, 54.05 \%$, and $16.53 \%$, for $\mathrm{B}_{1}, \mathrm{~B}_{2}, \mathrm{~B}_{3}$, and $\mathrm{B}_{4}$, respectively. The SMD for the mixture treatments increased by $55.41 \%, 65.11 \%, 7.13 \%$, and $9.17 \%$ for $\mathrm{B}_{1}: \mathrm{P}_{1}, \mathrm{~B}_{2}: \mathrm{P}_{2}, \mathrm{~B}_{3}: \mathrm{P}_{3}$, and $\mathrm{B}_{4}: \mathrm{P}_{4}$, respectively. SMD increased by $16.91 \%, 22.19 \%, 8.60 \%$, and $43.01 \%$ for $\mathrm{B}_{1}: \mathrm{P}_{1}, \mathrm{~B}_{2}: \mathrm{P}_{2}, \mathrm{~B}_{3}: \mathrm{P}_{3}$, and $\mathrm{B}_{4}: \mathrm{P}_{4}$, respectively. The exception was polymer application at rates of $\mathrm{P}_{2}(0.4 \%)$ and $\mathrm{P}_{3}(0.6 \%)$. Results indicate that the use of polymer reduced the soil moisture content when compared to the control. 


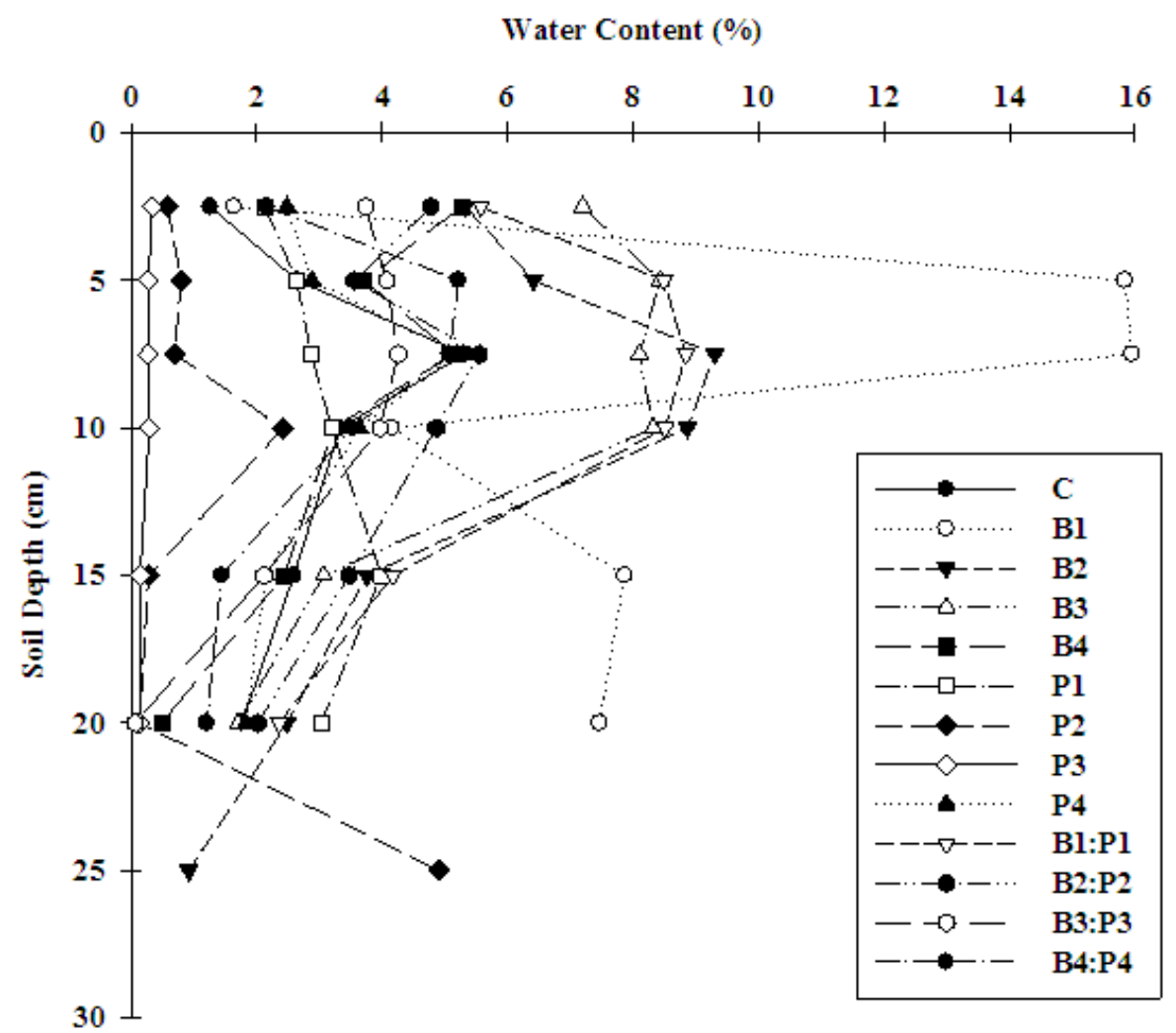

Figure 5. Effect of biochar, polymer, and mixture applications on water content distribution (percentage) in soil columns.

\subsection{Water Retention Curve}

Measured and simulated soil moisture characteristic curves for all treatments are presented in Figure 6. Increasing the rate of biochar and the mixture of biochar and polymer increased soil moisture content at both higher and lower water potentials as shown in Figure $6 \mathrm{a}-\mathrm{c}$. The water content at lower water potential increased by $6.01 \%, 7.39 \%, 7.71 \%$, and $8.12 \%$ for $\mathrm{B}_{1}, \mathrm{~B}_{2}, \mathrm{~B}_{3}$, and $\mathrm{B}_{4}$, respectively. The increase for the mixture treatments at the lower potential was $12.81 \%, 14.65 \%, 15.66 \%$, and $15.92 \%$ for $\mathrm{B}_{1}: \mathrm{P}_{1}, \mathrm{~B}_{2}: \mathrm{P}_{2}, \mathrm{~B}_{3}: \mathrm{P}_{3}$, and $\mathrm{B}_{4}: \mathrm{P}_{4}$, respectively. However, the use of polymer increased the soil moisture content by $2.49 \%, 2.61 \%, 2.96 \%$ and $5.53 \%$ at $\mathrm{P}_{1}, \mathrm{P}_{2}, \mathrm{P}_{3}$, and $\mathrm{P}_{4}$, respectively. The application of soil amendment as compared to untreated soil enhanced the available water especially at higher water potentials $(100 \mathrm{hPa})$. Table 3 shows that the F.C increased compared to control by $6.64 \%, 8.40 \%$, $8.98 \%$, and $9.77 \%$ for $B_{1}, B_{2}, B_{3}$, and $B_{4}$, respectively. The F.C. for each mixture increased by $11.64 \%$, $13.92 \% 14.94 \%$, and $15.13 \%$ for $\mathrm{B}_{1}: \mathrm{P}_{1}, \mathrm{~B}_{2}: \mathrm{P}_{2}, \mathrm{~B}_{3}: \mathrm{P}_{3}$ and $\mathrm{B}_{4}: \mathrm{P}_{4}$, respectively. Additionally, Table 3 shows the hydrological parameters of soil amended as affected by application rate of biochar, polymer, and mixtures of biochar and polymers. Significant differences were found in soil moisture content at saturation $\theta_{\mathrm{s}}$ and residual water $\theta_{\mathrm{r}}$. The results show significant differences in other parameters ( $\alpha$ and $n$ ) for van Genunchten model with application of biochar, polymer and the mixtures of biochar and polymers. 
Table 3. Fitted residual and saturated water contents, and parameters ( $\alpha$ and $n$ ) of the soil water retention model [33].

\begin{tabular}{|c|c|c|c|c|c|c|c|}
\hline \multirow{2}{*}{ Treatments } & $\theta_{s}$ & $\theta_{r}$ & $\mathbf{n}$ & $\alpha$ & W.C F. C $^{1}$ & W.C ${ }_{W . P}{ }^{2}$ & A. $W^{3}$ \\
\hline & $\left(\mathrm{cm}^{3} \mathrm{~cm}^{-3}\right)$ & $\left(\mathrm{cm}^{3} \mathrm{~cm}^{-3}\right)$ & & $\left(\mathrm{cm}^{-1}\right)$ & $\left(\mathrm{cm}^{3} \mathrm{~cm}^{-3}\right)$ & $\left(\mathrm{cm}^{3} \mathrm{~cm}^{-3}\right)$ & $\left(\mathrm{cm}^{3} \mathrm{~cm}^{-3}\right)$ \\
\hline $\mathrm{C}$ & 0.3009 & 0.0259 & 1.47 & 0.0489 & 0.1525 & 0.0383 & 0.1142 \\
\hline B1 & 0.3194 & 0.0248 & 1.463 & 0.0477 & 0.1634 & 0.0388 & 0.1246 \\
\hline B2 & 0.3235 & 0.0239 & 1.461 & 0.0467 & 0.1665 & 0.0385 & 0.1280 \\
\hline B3 & 0.3245 & 0.0228 & 1.457 & 0.0465 & 0.1675 & 0.0379 & 0.1296 \\
\hline B4 & 0.3257 & 0.0225 & 1.454 & 0.0462 & 0.1690 & 0.0380 & 0.1310 \\
\hline $\mathrm{LSD}_{0.05}$ & 0.00175 & 0.0015 & 0.005 & 0.0011 & 0.010 & 0.0001 & \\
\hline P1 & 0.3094 & 0.0256 & 1.47 & 0.0499 & 0.1551 & 0.0382 & 0.1169 \\
\hline P2 & 0.3098 & 0.0255 & 1.4769 & 0.0497 & 0.1540 & 0.0376 & 0.1164 \\
\hline P3 & 0.3108 & 0.0254 & 1.4765 & 0.0495 & 0.1547 & 0.0376 & 0.1171 \\
\hline $\mathrm{P} 4$ & 0.3189 & 0.0250 & 1.463 & 0.0493 & 0.1613 & 0.0387 & 0.1226 \\
\hline $\mathrm{LSD}_{0.05}$ & 0.001 & 0.0003 & 0.006 & 0.0001 & 0.0016 & 0.0002 & \\
\hline B 1:P 1 & 0.3454 & 0.0249 & 1.471 & 0.0486 & 0.1726 & 0.0393 & 0.1333 \\
\hline B 2:P 2 & 0.351 & 0.0239 & 1.4719 & 0.0466 & 0.1772 & 0.0388 & 0.1384 \\
\hline B 3:P 3 & 0.355 & 0.0219 & 1.4725 & 0.0456 & 0.1793 & 0.0372 & 0.1421 \\
\hline B 4:P 4 & 0.356 & 0.0214 & 1.4729 & 0.0454 & 0.1797 & 0.0367 & 0.1430 \\
\hline $\mathrm{LSD}_{0.05}$ & 0.04 & 0.0010 & 0.001 & 0.0003 & 0.020 & 0.001 & \\
\hline
\end{tabular}

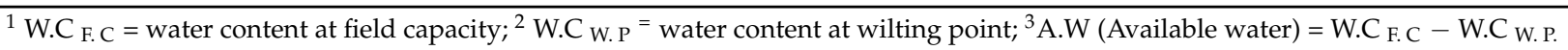



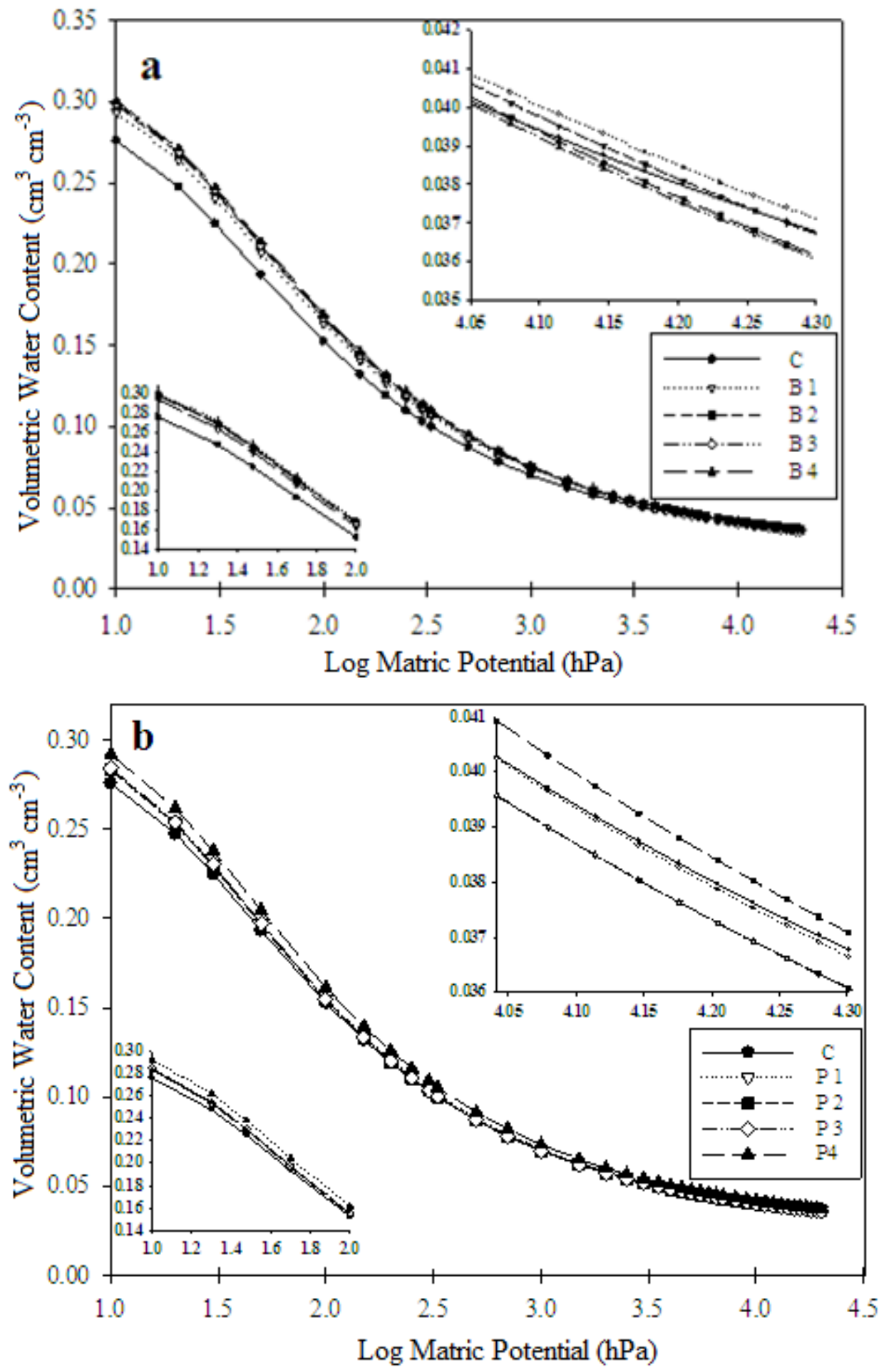

Figure 6. Cont. 


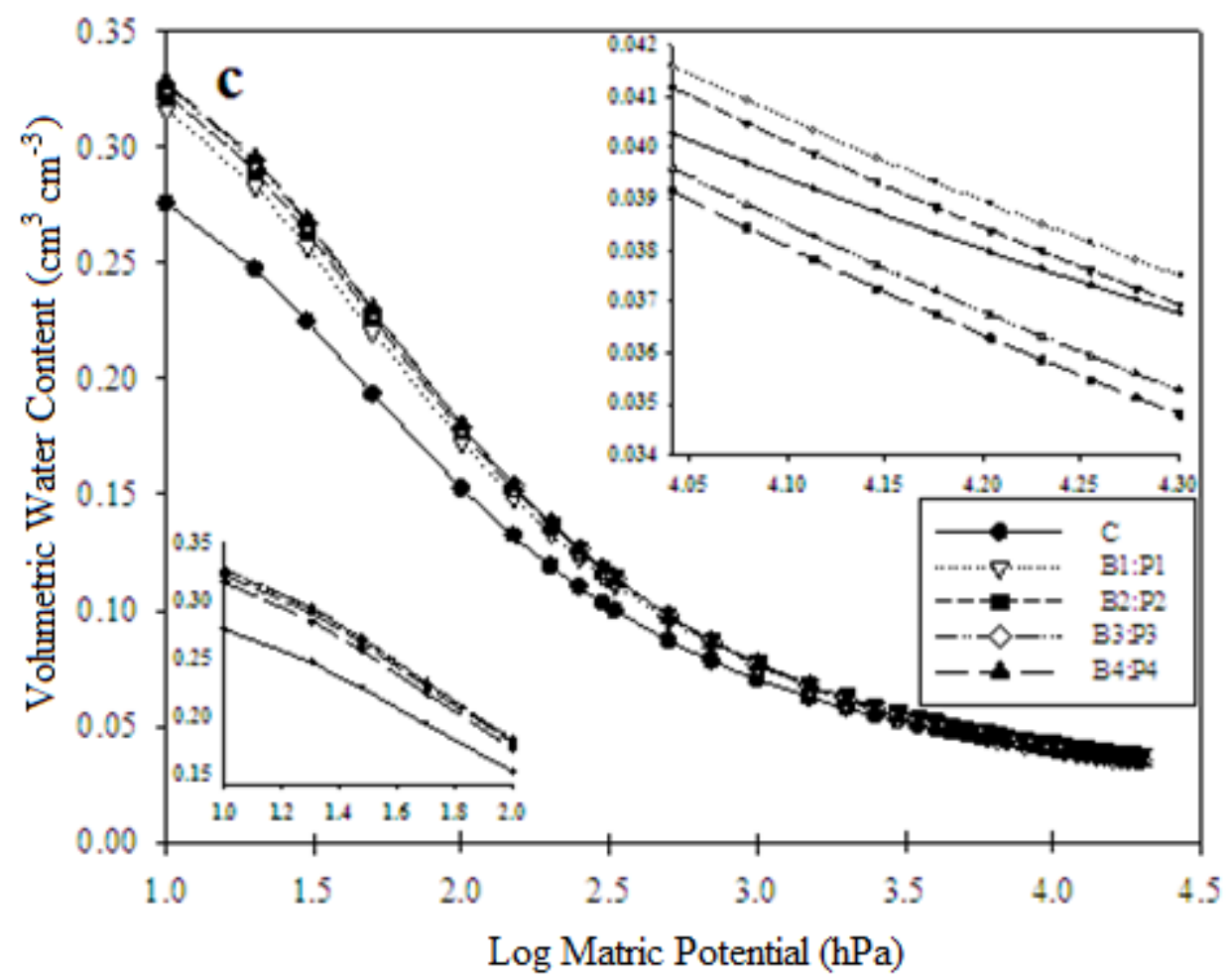

Figure 6. Effect of soil conditioners biochar (a), polymer (b), mixture (c) applications soil moisture characteristic curves.

\subsection{Aggregate Stability}

Figure 7a illustrates the percentages of stable aggregates, as affected by different soil amendments (biochar, polymer, and mixtures of biochar and polymers), in eight fraction sizes. For fraction size $0.22-0.125 \mathrm{~mm}$, aggregate stability (AS) increased with the application of $\mathrm{B}_{2}: \mathrm{P}_{2}$ and $\mathrm{P}_{4}$ treatments to $50.82 \%$ and $50 \%$, respectively. For fraction size $2-1 \mathrm{~mm}$, AS increased by $7.72 \%$ with the highest application to mixture rate $\mathrm{B}_{4}: \mathrm{P}_{4}$. However, for fraction size $0.63-0.38 \mathrm{~mm}$, AS decreased in all treatments except in untreated soil. For the fraction size of $<0.038 \mathrm{~mm}$, AS was corrected after dispersion of the soil and subtracted for the sand coarse fraction; the sand proportion was assumed constant in every size fraction. Figure $7 \mathrm{~b}$ shows the corrected sum of AS as affected by the increase in soil conditioner (biochar and polymer) applications. The corrected sum of AS increased for all treatments to $53.68 \%, 64.57 \%, 90.74 \%, 99.91 \%, 25.10 \%, 12.90 \%, 60.37 \%, 180.28 \%, 38.12 \%, 129.63 \%$, $70.52 \%$, and $85.69 \%$ for $\mathrm{B}_{1}, \mathrm{~B}_{2}, \mathrm{~B}_{3}, \mathrm{~B}_{4}, \mathrm{P}_{1}, \mathrm{P}_{2}, \mathrm{P}_{3}, \mathrm{P}_{4}, \mathrm{~B}_{1}: \mathrm{P}_{1}, \mathrm{~B}_{2}: \mathrm{P}_{2}, \mathrm{~B}_{3}: \mathrm{P}_{3}$, and $\mathrm{B}_{4}: \mathrm{P}_{4}$, respectively, as compared with untreated soil. MWD increased with increase in the application rate of biochar, and highest rate of polymer increased MWD by $31.82 \%, 28.70 \%, 34.21 \%, 25.85 \%, 53.55 \%, 56.22 \%$, $35.70 \%, 14.40 \%, 37.58 \%, 11.67 \%, 35.02 \%$, and $52.52 \%$ for $\mathrm{B}_{1}, \mathrm{~B}_{2}, \mathrm{~B}_{3}, \mathrm{~B}_{4}, \mathrm{P}_{1}, \mathrm{P}_{2}, \mathrm{P}_{3}, \mathrm{P}_{4}, \mathrm{~B}_{1}: \mathrm{P}_{1}, \mathrm{~B}_{2}: \mathrm{P}_{2}, \mathrm{~B}_{3}: \mathrm{P}_{3}$, and $\mathrm{B}_{4}: \mathrm{P}_{4}$, respectively, as compared with untreated soil.

\section{Discussion}

\subsection{Intermittent Evaporation}

In this study, it is evident that application of biochar to course-texture soils decreased the evaporation from soil columns. The biochar addition clearly enhanced the capacity of soil to retain water and, consequently, resulted in higher water conservation. This is also evident with application of the mixture of biochar and polymer at lower application rates. Biochar application reduced $\mathrm{CE}$ by $29.27 \%, 16.47 \%, 14.17 \%$, and $14.61 \%$ for $B_{1}, B_{2}, B_{3}$, and $B_{4}$, respectively. This finding is similar to other research reports on the addition of biochar [26,34-36]. Ibrahim, et al. [36] reported that CE was 
reduced by $13.3-21.2 \%$ for soils treated with conocarpus biochar and the amount of water conserved increased by $6.3 \%$.

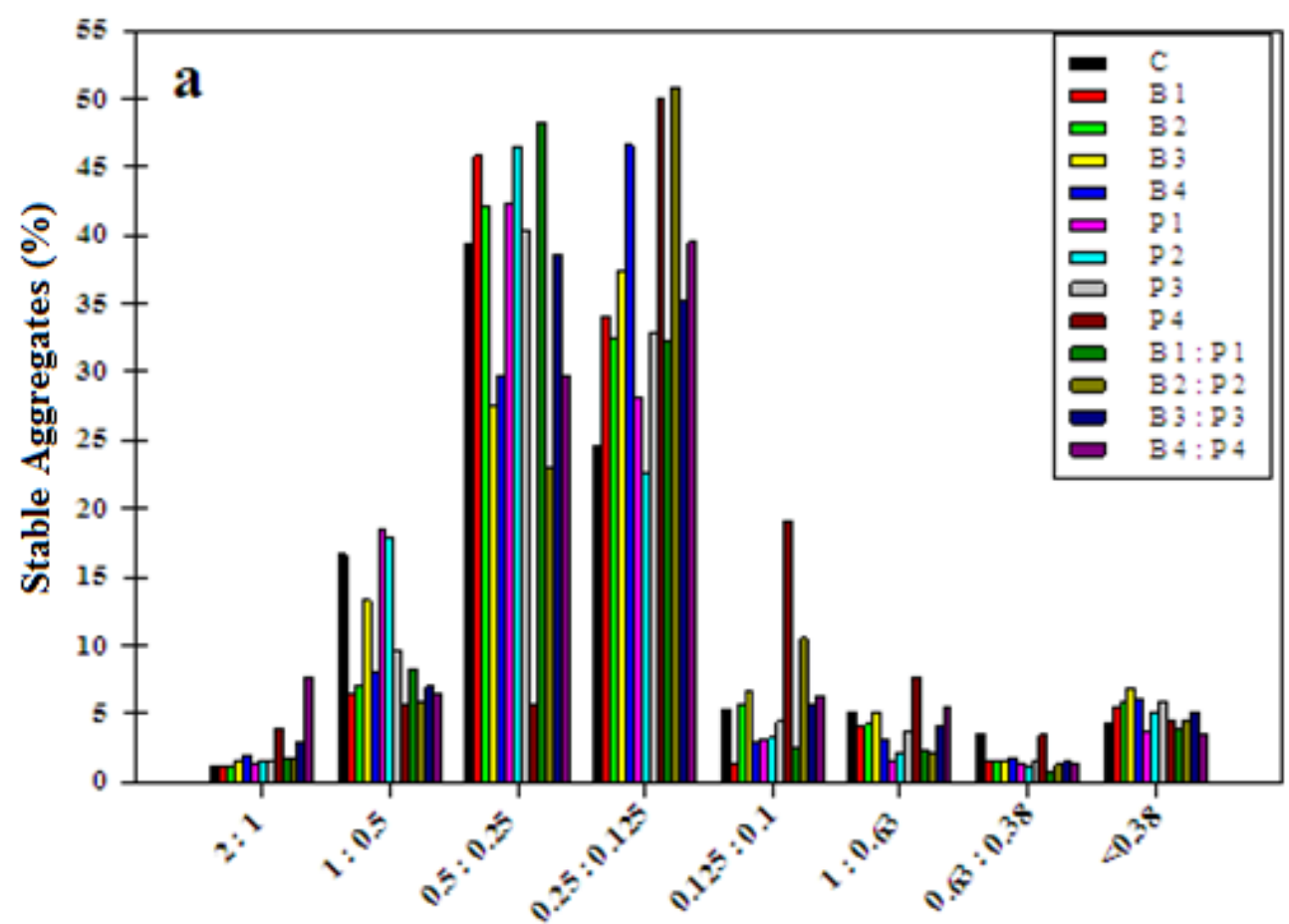

Size Diamater (mm)

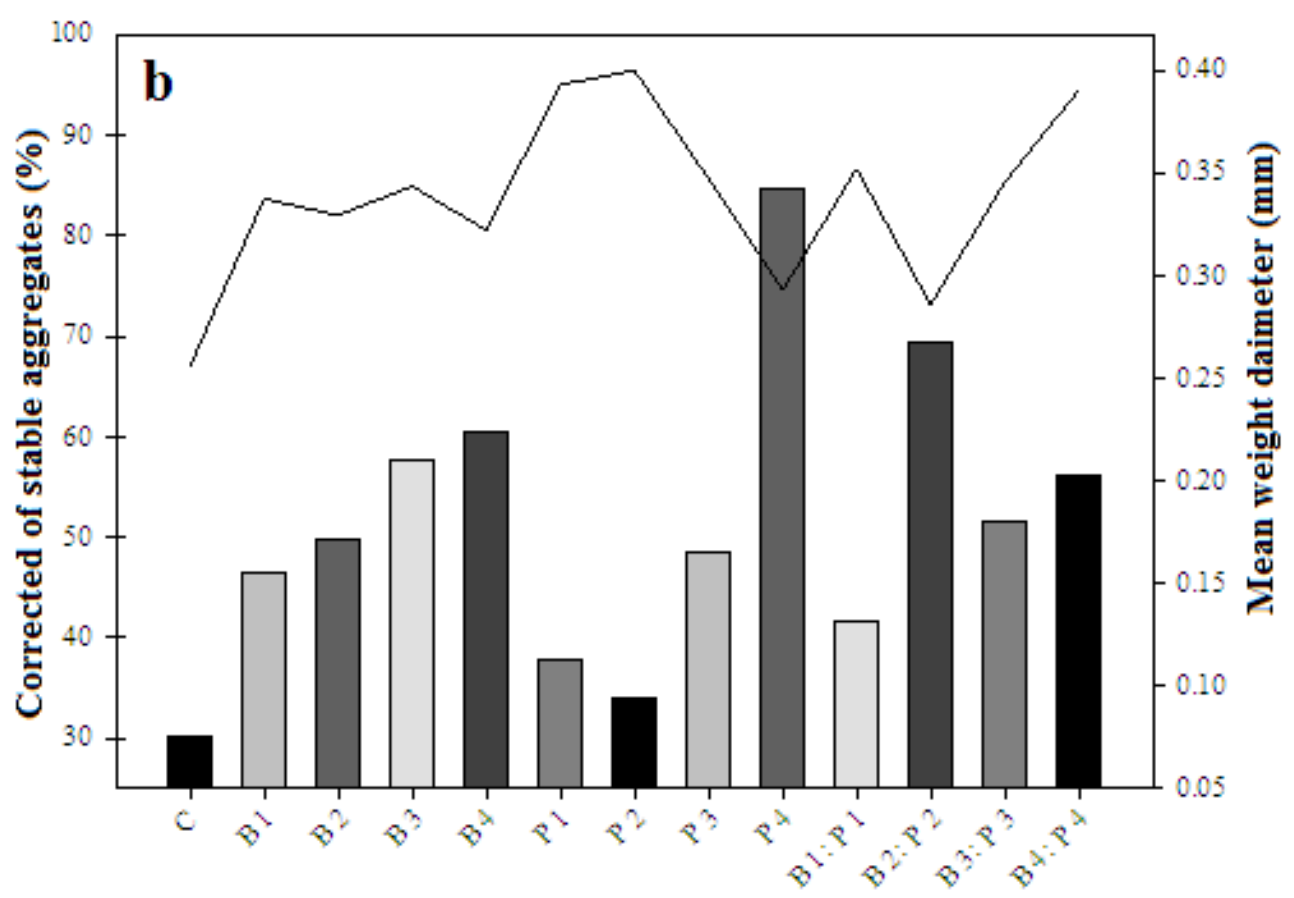

Soil Conditioners

Figure 7. Effect of biochar, polymer and mixture applications on the percentage of water-stable aggregates (\%) (a), and the corrected sum of water-stable aggregates (\%) and mean weight diameter $(\mathrm{mm})(\mathbf{b})$. 
The addition of polymer decreased the $\mathrm{CE}$ at low concentrations, and increases in the polymer rates to $0.4 \%, 0.6 \%$ and $0.8 \%$ led to increases in CE by $6.87 \%, 13.81 \%$, and $14.86 \%$, respectively, compared with untreated soil. Thus, the amount of water conserved at these rates was lower than the control or other treatments. Increasing the polymer rate to $0.8 \%$ increased $\mathrm{CE}$; this finding is similar to results reported by Al-Omran et al. [1] on the use of Jalma conditioners. They reported a similar influence of Jalma on CI at $0.05 \mathrm{~m}$ surface layer due to it is effect on aggregation and swelling. These two phenomena affect CE.

\subsection{Infiltration}

The results indicated that application of biochar and the mixture of polymer and biochar restricted water movement in soil. Thus, the soil treated with biochar needed more time to advance in the soil columns as the rate increased from $2 \%$ to $8 \%$. The lowest values of infiltration were observed with higher concentration of biochar $(8 \%)$, and this can be explained by the settling of very fine particles of biochar into the soil pore, blocking soil pores and reducing infiltration [36,37]. Busscher et al. [38] and Ibrahim et al. [27] concluded that biochar addition to sandy soils having coarse texture can lower water percolation through soil and thus conserve soil moisture, resulting in more water available to plants. The application of polymers with rates from $0.2 \%$ to $0.8 \%$ significantly increased CI; this behavior may be attributed to the swelling effect of the higher application of polymer. The same finding was reported using super absorbent polymer by [39].

\section{Soil Water Retention}

The positive impact of application of biochar in soil led to improved soil properties, including an increase the capacity of the soil to retain water at higher and lower potentials, and an increase in water content at F.C with the addition of biochar between $7.14 \%$ and $10.81 \%$ for $\mathrm{B}_{1}$ and $\mathrm{B}_{4}$, respectively, and $1.7 \%$ to $5.77 \%$ for polymer application rates $\mathrm{P}_{1}$ to $\mathrm{P}_{4}$. The highest increase of F.C was $13.18 \%$ to $17.84 \%$ for $\mathrm{B}_{1}: \mathrm{P}_{1}$ and $\mathrm{B}_{4}: \mathrm{P}_{4}$, respectively. There was an increase of welting point (WP) from $0.52 \%$ to $1.35 \%$, and $1.3 \%$ to $2.6 \%$, for lower application of biochar and the mixture of biochar and polymers, respectively. Similar results were reported by Kinney et al. [40] in which they found that water retained at F.C. was increasing by $25 \%$ with the addition of biochar using sandy soil. The increase of water retained might be attributed to the increasing number of small pores in soil after the addition of biochar [41]. Additionally, a high surface area of biochar could explain the increased soil water retention of sandy soil [31]. Thus, the results indicate that adding biochar may have enhanced the soil pores effect on soil water content compared to untreated soil. Also, biochar decreased infiltration and saturated Ks. However, polymer increased infiltration with addition of polymers rates of $0.2 \%$ to $0.8 \%$. Biochar application also affected SA with all biochar rates. MWD increased by increasing application rate. The biochar and polymer amendment enhanced the formation and stabilization of the soil macro aggregates, especially in the sandy loam soil $[27,42]$.

\section{Conclusions}

In this study, the impact of date palm biochar rates between $2 \%$ and $8 \%$, polymer rates between $0.2 \%$ and $0.8 \%$, and mixture of these was investigated for improvement of hydro-physical properties of sandy soils using fresh water. The results showed that $\mathrm{CE}$ from treated soil with biochar was reduced by $29.27 \%$ and $14.61 \%$ for $\mathrm{B}_{1}$ and $\mathrm{B}_{4}$, respectively, and $0.55 \%$ to $17.40 \%$ for $\mathrm{B}_{1}: \mathrm{P}_{1}$ and $\mathrm{B}_{4}: \mathrm{P}_{4}$, respectively. However, the application of polymer increased $\mathrm{CI}$ by $6.87 \%$ to $14.86 \%$, when increasing the rate from $0.2 \%$ to $0.8 \%$, compared to untreated soil. The application of biochar enhanced the capacity of soil to conserve water; the amount of water conserved increased by $68.03 \%, 54.36 \%, 54.05 \%$, and $16.53 \%$ for rates $2 \%, 4 \%, 6 \%$, and $8 \%$, respectively.

This study found that the use of the mixture of $\mathrm{B}_{4}: \mathrm{P}_{4}$ can improve the hydro-physical properties of sandy soil in arid environments; this mixture has the highest water content at F.C and available water compared to the other treatments and control. Conversely, the addition of date palm biochar at a 
low rate $\left(\mathrm{B}_{1}\right)$ to sandy soil improved soil hydraulic properties (water retention, water holding capacity, Ks, and infiltration ate) and reduced CE. Therefore, under arid conditions where water shortages and limited water quality are issues, the date palm biochar might be a promising soil amendment for soil productivity and could improve crop productivity for crops exposed to water stress in sandy soils.

Supplementary Materials: The following are available online at http:/ / www.mdpi.com/2071-1050/10/12/4642/ s1.

Author Contributions: Formal analysis, A.A., A.A.-O. and A.A.A.; Methodology, A.A.-O. and A.A.A.; Writing —original draft, A.A.-O. and A.A.A.; Writing—review \& editing.

Funding: Deanship of the Scientific Researches, King Saud University and Agricultural Researches Center, College of Food and Agricultural Sciences: KSU11451.

Acknowledgments: The authors wish to thank King Saud University, Deanship of Scientific Research, College of Food and Agricultural Sciences, Research Center for supporting this work. The authors also thank the Deanship of Scientific Research and RSSU at King Saud University for their technical support.

Conflicts of Interest: The authors declare no conflict of interest.

\section{References}

1. Al-Omran, A.M.; Mustafa, M.A.; Shalaby, A.A. Intermittent evaporation from soil columns as affected by gel-forming conditioners. Soil Sci. Soc. Am. J. 1987, 51, 1593-1599. [CrossRef]

2. Hueso-González, P.; Martínez-Murillo, J.F.; Ruiz-Sinoga, J.D. The impact of organic amendments on forest soil properties under Mediterranean climatic conditions. Land Degrad. Dev. 2014, 25, 604-612. [CrossRef]

3. Mann, K.K.; Schumann, A.W.; Obreza, T.A.; Sartain, J.B.; Harris, W.G.; Shukla, S. Analyzing the efficiency of soil amendments and irrigation for plant production on heterogeneous sandy soils under greenhouse conditions. J. Plant Nutr. Soil Sci. 2011, 174, 925-932. [CrossRef]

4. Ahmad, S.; Ghafoor, A.; Akhtar, M.E.; Khan, M.Z. Ionic displacement and reclamation of soline-sodic soils using chemical amendments and crop rotation. Land Degrad. Dev. 2013, 24, 170-178. [CrossRef]

5. Obia, A.; Mulder, J.; Martinsen, V.; Cornelissen, G.; Børresen, T. In situ effects of biochar on aggregation, water retention and porosity in light-textured tropical soils. Soil Tillage Res. 2016, 155, 35-44. [CrossRef]

6. Baiamonte, G.; De Pasquale, C.; Marsala, V.; Cimò, G.; Alonzo, G.; Crescimanno, G.; Conte, P. Structure alteration of a sandy-clay soil by biochar amendments. J. Soils Sediments 2015, 15, 816-824. [CrossRef]

7. Laird, D.A.; Fleming, P.; Davis, D.D.; Horton, R.; Wang, B.; Karlen, D.L. Impact of biochar amendments on the quality of a typical midwestern agricultural soil. Geoderma 2010, 158, 443-449. [CrossRef]

8. Asai, H.; Samson, B.K.; Stephan, H.M.; Songyikhangsuthor, K.; Homma, K.; Kiyono, Y.; Inoue, Y.; Shiraiwa, T.; Horie, T. Biochar amendment techniques for upland rice production in northern laos. Field Crops Res. 2009, 111, 81-84. [CrossRef]

9. Uzoma, K.C.; Inoue, M.; Andry, H.; Fujimaki, H.; Zahoor, A.; Nishihara, E. Effect of cow manure biochar on maize productivity under sandy soil condition. Soil Use Manag. 2011, 27, 205-212. [CrossRef]

10. Novak, J.M.; Lima, I.; Xing, B.; Gaskin, J.W.; Steiner, C.; Das, K.C.; Ahmedna, M.; Rehrah, D.; Watts, D.W.; Busscher, W.J.; et al. Characterization of designer biochar produced at different temperatures and their effects on a loamy sand. Ann. Environ. Sci. 2009, 3, 195-206.

11. Safari, N.; Aliasgharzad, N.; Asghari, S. The effects of polyacrylamide on the parameters of physical quality in a clay loam soil selected from semiarid region. J. Soil Environ. 2015, 1, 10-17.

12. Hussien, R.A.; Donia, A.M.; Atia, A.A.; El-Sedfy, O.F.; El-Hamid, A.A.; Rashad, R.T. Studying some hydro-physical properties of two soils amended with kaolinite-modified cross-linked poly-acrylamides. Catena 2012, 92, 172-178. [CrossRef]

13. Liu, Z.; Miao, Y.; Wang, Z.; Yin, G. Synthesis and characterization of a novel super-absorbent based on chemically modified pulverized wheat straw and acrylic acid. Carbohydr. Polym. 2009, 77, 131-135. [CrossRef]

14. Beckett, C.T.; Augarde, C.E. Prediction of soil water retention properties using pore-size distribution and porosity. Can. Geotech. J. 2013, 50, 435-450. [CrossRef]

15. Chen, Z.; Liu, M.; Qi, X. Synthesis and Properties of a Superabsorbent Polymer Prepared by Copolymerization of Sodium Acrylate with Sodium 1-(Acryloyloxy) propan-2-yl Phosphate. Macromol. React. Eng. 2007, 1, 275-283. [CrossRef] 
16. Han, Y.G.; Yang, P.L.; Luo, Y.P.; Ren, S.M.; Zhang, L.X.; Xu, L. Porosity change model for watered super absorbent polymer-treated soil. Environ. Earth Sci. 2010, 61, 1197-1205. [CrossRef]

17. Zohuriaan-Mehr, M.J.; Omidian, H.; Doroudiani, S.; Kabiri, K. Advances in non-hygienic applications of superabsorbent hydrogel materials. J. Mater. Sci. 2010, 45, 5711-5735. [CrossRef]

18. Islam, M.R.; Hu, Y.; Mao, S.; Mao, J.; Eneji, A.E.; Xue, X. Effectiveness of a water-saving super-absorbent polymer in soil water conservation for corn (Zea mays L.) based on eco-physiological parameters. J. Sci. Food Agric. 2011, 91, 1998-2005. [CrossRef]

19. Hou, X.; Li, R.; He, W.; Dai, X.; Ma, K.; Liang, Y. Superabsorbent polymers influence soil physical properties and increase potato tuber yield in a dry-farming region. J. Soils Sediments 2018, 18, 816-826. [CrossRef]

20. Qin, S.H.; Wang, D.; Zhang, J.L.; Dai, H.L.; Niu, G.Q.; Guo, R. Effects of aquasorbs on soil water characteristic and yield formation of potato. J. Gansu Agric. Univ. 2013, 2, 008.

21. El-Asmar, J.; Jaafar, H.; Bashour, I.; Farran, M.T.; Saoud, I.P. Hydrogel banding improves plant growth, survival, and water use efficiency in two calcareous soils. CLEAN-Soil Air Water 2017, 45, 1700251. [CrossRef]

22. Alghamdi, A.G.; Aly, A.A.; Al-Omran, A.M.; Alkhasha, A. Impact of biochar, bentonite, and compost on physical and chemical characteristics of a sandy soil. Arab. J. Geosci. 2018, 11, 670-678. [CrossRef]

23. Gupta, S.K.; Gupta, I.C.; Yaduvanshi, N.P.S. Standard Methods for Analysis of Soil Plant Water; Scientific Publishers: Jodhpur, India, 2012.

24. Adams, W.A. The effect of organic matter on the bulk and true densities of some uncultivated podsoilc soils. J. Soil Sci. 1973, 24, 11-17. [CrossRef]

25. Siesler, H.W. Fourier transform infrared (ftir) spectroscopy in polymer research. J. Mol. Struct. 1980, 59, 15-37. [CrossRef]

26. Ibrahim, H.M.; Al-Wabel, M.I.; Usman, A.R.A.; Al-Omran, A. Effect of conocarpus biochar application on the hydraulic properties of a sandy loam soil. Soil Sci. 2013, 178, 165-173. [CrossRef]

27. Ibrahim, A.; Usman, A.R.A.; Al-Wabel, M.I.; Nadeem, M.; Ok, Y.S.; Al-Omran, A. Effects of conocarpus biochar on hydraulic properties of calcareous sandy soil: Influence of particle size and application depth. Arch. Agron. Soil Sci. 2016, 63, 185-197. [CrossRef]

28. Philip, J.R. The theory of infiltration: The infiltration equation and its solution. Soil Sci. 1957, 83, 345-357. [CrossRef]

29. Klute, A. Physical and Mineralogical Methods of Soil Analysis; American Society of Agronomy: Madison, WI, USA, 1986.

30. Nimmo, J.R.; Perkins, K.S. Aggregate Stability and Size Distribution. In Methods of Soil Analysis; Madison, Wisconsin, Soil Science Society of America: Madison, WI, USA, 2002; Volume 4, pp. 317-328.

31. Lal, R.; Shukla, M.K. Principles of Soil Physics; CRC Press: Boca Raton, FL, USA, 2004.

32. Tang, J.; Mo, Y.; Zhang, J.; Zhang, R. Influence of biological aggregating agents associated with microbial population on soil aggregate stability. Appl. Soil Ecol. 2011, 47, 153-159. [CrossRef]

33. van Genuchten, M.T. A closed-form equation for predicting the hydraulic conductivity of unsaturated soils. Soil Sci. Soc. Am. J. 1980, 44, 892-898. [CrossRef]

34. Akhter, J.; Mahmood, K.; Malik, K.; Mardan, A.; Ahmad, M.; Iqbal, M. Effects of hydrogel amendment on water storage of sandy loam and loam soils and seedling growth of barley, wheat and chickpea. Plant Soil Environ. 2004, 50, 463-469. [CrossRef]

35. Herath, H.M.S.K.; Camps-Arbestain, M.; Hedley, M. Effect of biochar on soil physical properties in two contrasting soils: An alfisol and an andisol. Geoderma 2013, 209-210, 188-197. [CrossRef]

36. Mukherjee, A.; Lal, R. Biochar impacts on soil physical properties and greenhouse gas emissions. Agronomy 2013, 3, 313-339. [CrossRef]

37. George, C.; Wagner, M.; Kücke, M.; Rillig, M.C. Divergent consequences of hydrochar in the plant-soil system: Arbuscular mycorrhiza, nodulation, plant growth and soil aggregation effects. Appl. Soil Ecol. 2012, 59, 68-72. [CrossRef]

38. Busscher, W.J.; Novak, J.M.; Evans, D.E.; Watts, D.W.; Niandou, M.A.S.; Ahmedna, M. Influence of pecan biochar on physical properties of a norfolk loamy sand. Soil Sci. 2010, 175, 10-14. [CrossRef]

39. Al-Omran, A.M.; Mustafa, M.A.; Al-Darby, A.M.; Shalaby, A.A. Gel-conditioned barriers for water management of sandy soils. Irrig. Sci. 1991, 12, 7-12. [CrossRef]

40. Kinney, T.J.; Masiello, C.A.; Dugan, B.; Hockaday, W.C.; Dean, M.R.; Zygourakis, K.; Barnes, R.T. Hydrologic properties of biochars produced at different temperatures. Biomass Bioenergy 2012, 41, 34-43. [CrossRef] 
41. Glaser, B.; Lehmann, J.; Zech, W. Ameliorating physical and chemical properties of highly weathered soils in the tropics with charcoal-A review. Boil. Fertil. Soils 2002, 35, 219-230. [CrossRef]

42. Liang, B.; Lehmann, J.; Solomon, D.; Kinyangi, J.; Grossman, J.; O'neill, B.; Skjemstad, J.O.; Thies, J.; Luizao, F.J.; Petersen, J.; et al. Black carbon increases cation exchange capacity in soils. Soil Sci. Soc. Am. J. 2006, 70, 1719-1730. [CrossRef] 